\title{
PELATIHAN AKUNTANSI PERPAJAKAN PADA CV AMADEUS JAYA MAKMUR
}

\author{
Viriany $^{1}$, Monica Agatha ${ }^{2}$, Kinaya Arung Laby $^{3}$ \\ ${ }^{1}$ Program Studi S1 Akuntansi, Universitas Tarumanagara Jakarta \\ Email:viriany@fe.untar.ac.id \\ ${ }^{2}$ Program Studi S1 Akuntansi, Universitas Tarumanagara Jakarta \\ Email:monicaagatha@gmail.com \\ ${ }^{3}$ Program Studi S1 Akuntansi, Universitas Tarumanagara Jakarta \\ Email:kinaya.arla@gmail.com
}

\begin{abstract}
Based on our conversations to partner, the Untar Community Service team found that CV Amadeus Jaya Makmur needed to fulfill its tax obligations. In relation to CV AJM's tax reporting and payment, the Untar Commuintiy Service Team proposed to conduct training related to tax accounting and the company agreed to accept the proposal. The Training will be conduct for three times. Each meeting will be held in 2 until 3 hours.The Training conducted in October 2, 9 and 19 using an online platform. This training run well altough the participant seems not very understood the content of this training. PKM Untar willing to help if there is a questions in implemented this training.
\end{abstract}

Keywords: Training; Tax Accounting

\begin{abstract}
ABSTRAK
Berdasarkan hasil observasi selama ini ke lokasi mitra, tim Pengabdian Kepada Masyarakat Untar menemukan bahwa CV Amadeus Jaya Makmur perlu melakukan kewajiban perpajakannya. Berkaitan dengan pelaporan dan pembayaran pajak CV Amadeus Jaya Makmur ini maka Tim Pengabdian Kepada Masyarakat Untar mengusulkan untuk melakukan pelatihan yang berkaitan dengan akuntansi perpajakan dan perusahaan setuju untuk menerima usul dari Tim Pengabdian Kepada Masyarakat Universitas Tarumanagara. Pelatihan dilakukan selama 3 kali pertemuan secara daring. Setiap pertemuan berlangsung kurang lebih 2-3 jam. Pelatihan dilakukan pada tanggal 2,9 dan 16 Oktober 2021 dengan menggunakan platform daring. Pelatihan berlangsung dengan baik secara keseluruhan walaupun mungkin ada sedikit kendala di pemahaman materi oleh peserta pelatihan. PKM Untar membuka kesempatan untuk bertanya lebih lanjut mengenai akuntansi perpajakan di kemudian hari apabila dirasakan diperlukan.
\end{abstract}

Kata kunci: pelatihan; akuntansi perpajakan

\section{PENDAHULUAN}

CV Amadeus Jaya Makmur baru didirikan pada awal Januari 2020. CV ini bergerak di bidang penjualan lens cleaner (pembersih lensa kacamata). Sebelumnya penjualan dilakukan secara pribadi oleh pemilik perusahaan dan tidak mempunyai badan hukum khusus. Untuk ketertiban pembukuan dan perpajakan maka pemilik mendirikan badan usaha yang bernama CV Amadeus Jaya Makmur.

Sementara ini omzet penjualan masih berada di bawah 4,8 Milyar setahun sehingga masih dikategorikan sebagai UMKM dari sisi pajak dan membayar pajak dengan menggunakan Peraturan Pemerintah No.23 tahun 2018. Dibawah Peraturan Pemerintah No 23 ini maka CV Amadeus akan dikenakan pajak penghasilan sebesar $0.5 \%$ sebulan yang dihitung dari total pendapatan bruto bulan yang bersangkutan. 
Struktur organisasi CV Amadeus Jaya Makmur adalah sebagai berikut :

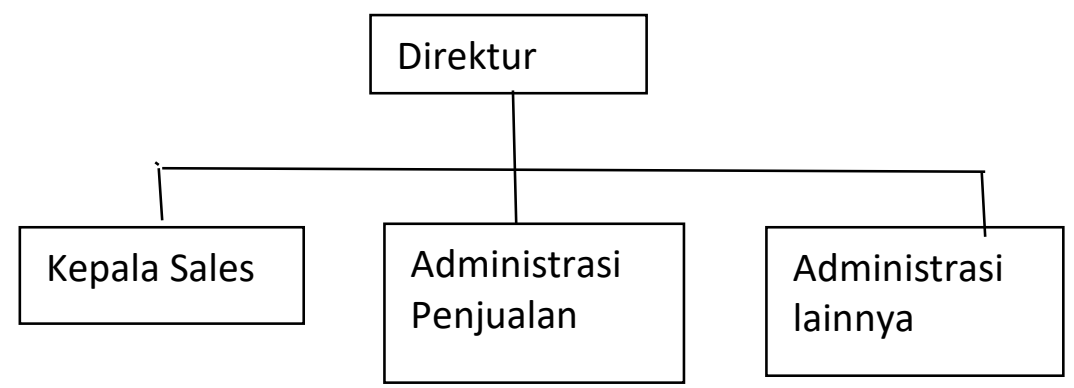

Gambar 1. Struktur Organisasi CV Amadeus Jaya Makmur

Adapun uraian pekerjaan yang dilakukan oleh masing-masing karyawan adalah sebagai berikut: Kepala Sales

1. Kepala Sales membawahi 2 orang sales

2. Kepala Sales merangkap sales juga di area yang berbeda dengan kedua sales lainnya

3. Bertugas melakukan penjualan dan memantau penjualan yang dilakukan oleh sales Administrasi Penjualan :

1. Membuat faktur penjualan

2. Merekap penjualan secara sederhana

3. Menagih piutang

4. Koodinasi dengan sales untuk beberapa hal seperti pemberian diskon, barang promosi

5. Mengawasi Gudang

6. Mencatat persediaan di Gudang

Administrasi lainnya :

1. Mencatat pembelian

2. Mencatat pengeluaran dan penerimaan kas kecil

3. Mencatat pengeluaran dan penerimaan bank

4. Bertugas sebagai kasir

5. Membuat faktur pembelian

6. Melunasi hutang dengan persetujuan Direktur

Total Karyawan yang ada di CV Amadeus berjumlah 5 orang.

Sebagai CV baru, masih banyak hal yang perlu dilengkapi di CV ini. Tim Pengabdian Kepada Masyarakat Universitas Tarumanagara akan memulai dulu dari Pelatihan Akuntansi Sederhana di semester lalu. Di semester ini dapat dilakukan pelatihan akuntansi perpajakan. Di semester berikutnya dapat memulai menyusun standar operasional prosedur atau bahkan dapat mengajukan pelatihan software akuntansi apabila memungkinkan.

\section{Kewajiban Perpajakan}

Ada dua hal yang tidak dapat dihindari dalam dunia ini, yang pertama adalah kematian dan yang kedua adalah pajak. Karena keduanya ini harus dihadapi oleh semua orang suatu hari nanti. Indonesia dibawah kementrian keuangan sedang giat-giatnya mensosialisasi perpajakan. Kelihatannya pemerintah memang serius mengumpulkan pajak dalam membiayai negara terutama di pandemi Covid 19 ini, di mana negara membiaya vaksin secara gratis, memberikan pelayanan rumah sakit secara gratis dan semuanya butuh biaya yang besar yang hanya dapat diperolah dari pemungutan pajak. Ini memang diijinkan karena salah satu fungsi dari pemungutan pajak adalah fungsi bugetair dan regularend. Pajak memang dipungut untuk 
membiayai pengeluaran negara. Bahkan ada salah satu definisi pajak yang menyatakan bahwa pemungutan pajak dapat dipaksakan selama itu untuk membiayai pengeluaran negara, dan rakyat yang membayar pajak tidak dapat menuntut pemerintah untuk memberikan pengembalian kepada mereka secara langsung (Resmi, 2017).

Menurut Mangoting dalam Pratiwi (2021) pajak adalah sumber keuangan negara (fungsi Budgetair) dan pengatur (regularend). Pajak dapat dikenakan secara langsung, pajak tidak langsung. Contoh pajak yang dikenakan secara langsung adalah PPN (Pajak Pertambahan Nilai). Sedangkan contoh pajak yang tidak dikenakan secara langsung adalah PPH (Pajak Penghasilan).

Pajak penghasilan sendiri lebih dikenal sebagai pajak pendapatan pada jaman dulu, seiring berkembangnya waktu maka pajak pendapatan ini disebut sebagai pajak penghasilan. (Darussalam, 2020)

Siapa saja yang wajib membayar pajak? Semua orang baik pribadi maupun perusahaan yang berbadan hukum yang mempunyai hak dan kewajiban perpajakan sesuai dengan ketentuan peraturan perundang-undangan perpajakan (Asfa, 2017).

Wajib Pajak Badan memiliki 3 tarif yang dikenakan atas penghasilan badan yang diatur oleh UU Perpajakan di Indonesia :

1. P P No.23 tahun 2018

2. Pasal 31 E UU PPH

3. Pasal 17 ayat 1 (b) UU PPH

P P No.23 tahun 2018 memiliki tarif 0,5\% dari peredaran bruto (omzet) (Sularsih, 2018). Apabila sebuah badan memiliki peredaran bruto kurang dari atau sama dengan 4,8 Milyar setahun maka boleh menggunakan tarif ini. Batas waktu penggunaan PP No 23 tahun 2018 ini adalah 7 tahun pajak untuk Wajib Pajak orang Pribadi , 4 tahun pajak untuk Wajib Pajak Badan berbentuk koperasi, CV atau Firma dan 3 tahun pajak untuk wajib pajak berbentuk PT

Tarif lainnya yaitu pasal 31 E Undang-undang PPH. Untuk Wajib Pajak Badan yang mempunyai peredaran bruto diatas 4,8 M sampai dengan 50 Milyar setahun berhak mendapatkan fasilitas pengurangan tarif umum sebesar $50 \%$ dari tarif yang berlaku.

Tarif umum diatur dengan pasal 17 ayat 1(b) Undang-undang PPH, yaitu sebesar 25\%. Namun menurut PP 30 tahun 2020 tarif ini akan diturunkan perlahan yaitu sebesar 22\% final untuk tahun 2020 dan akan diturunkan menjadi 20\% pada tahun berikutnya (Prasetya, 2021).

Selain Pajak Penghasilan di atas, Wajib Pajak badan mempunyai kewajiban juga untuk membayar pajak lainnya sesuai dengan transaksi yang dilakukan oleh badan seperti PPH pasal 23, PPH pasal 22, PPH pasal 21, PPH pasal 4 ayat 2, PPN, PPH pasal 25, PPH pasal 28 atau PPH pasal 29 dan juga PPN (Pajak Pertambahan Nilai).

\section{METODE PELAKSANAAN PKM}

Berdasarkan hasil observasi awal dan diskusi yang dilakukan tim PKM Untar dengan pihak CV AJM, maka tim PKM Untar menawarkan solusi untuk Melakukan pelatihan akuntansi perpajakan. Karena kondisi pandemi Covid yang tidak memungkinkan untuk melakukan pelatihan secara luring (tatap muka) maka pelatihan dilakukan secara daring (online) dengan menggunakan platform Zoom atau Google meet atau Microsoft Teams.

Pelatihan akan dilakukan sebanyak 3 kali yaitu:

a. Sabtu, 2 Oktober 2021, waktu pelatihan kurang lebih 2-3 jam.

b. $\quad$ Sabtu, 9 Oktober 2021, waktu pelatihan kurang lebih 2-3 jam.

c. Sabtu, 16 Oktober 2021, waktu pelatihan kurang lebih 2-3 jam. 
Dalam PKM ini dilakukan pelatihan akuntansi perpajakan kepada mitra dengan cara memberikan materi pelatihan dengan power point juga penjelasan soal secara singkat, juga melakukan diskusi dan memberikan kesempatan untuk bertanya kepada mitra.

Ada beberapa metode pelatihan seperti yang dikutip dari Nana Sudjana (2010). Metode pelatihan ada yang dikenal dengan metode ceramah. Metode ini seperti ceramah di mesjid atau di gereja, hanya bersifat satu arah dan pendengar tidak diberikan kesempatan untuk bertanya. Ada kelebihan metode ini yaitu pendengar bisa mendengar secara lengkap tanpa diganggu oleh apapun, dan pembicara biasanya lebih fokus dalam menyampaikan materi. Kekurangannya adalah bila ada yang mengganjal maka pendengar tidak bisa bertanya dan tidak akan mendapatkan penjelasan lebih lanjur, pendengar perlu mencari tahu sendiri.

Metode berikutnya ada metode tanya jawab, dalam metode ini pendengar akan bertanya dan pembicara akan menjawab. Kelebihan metode ini adalah suasana akan menjadi lebih hidup dan pendengar akan lebih mengerti materi yang disampaikan, selain itu juga biasanya akan banyak tergali sesuai dengan praktek yang berlaku.

$\mathrm{S}$ elain itu ada juga metode diskusi, pendengar dikelompokkan dalam beberapa grup dan diberikan tema untuk berdiskusi. Lalu pembicara berperan sebagai moderator. Ada juga metode lainnya seperti metode resitasi, metode kerja kelompok, metode demonstrasi , eksperimen, sosiodrama, penyelesaian masalah, kerja beregu, latihan, karyawisata, dan terakhir metode simulasi.

\section{HASIL DAN PEMBAHASAN}

Modul Akuntansi Perpajakan untuk CV Amadeus Jaya Makmur terdiri dari 3 modul yaitu :

1. Modul 1

Modul ini berisi pendahuluan yang membahas definisi pajak, jenis pajak, pengertian pembukuan bagi wajib pajak

2. Modul 2

Modul 2 berisi materi mengenai Pajak Pertambahan Nilai (PPN), pengertian beserta perhitungan yang dibutuhkan termasuk jurnal PPN.

3. Modul 3

Modul 3 ini berisi materi mengenai Pajak Penghasilan yang meliputi $\mathrm{PPh}$ pasal 21, $\mathrm{PPh}$ pasal 23, PPh 4 ayat 2 , PPh pasal 25, PPh pasal 28 dan PPh pasal 29. Membahas mengenai pengertian, hitungan dan jurnalnya.

\section{Pelatihan ke-1}

Pelatihan dilakukan pada hari Sabtu, 2 Oktober 2021 pk 13.00 sampai dengan 14.30. Dalam pelatihan ini, Tim Pengabdian kepada masyarakat Universitas Tarumagara menjelaskan materi yang terdapat pada modul 1.

Pertama-tama yang dibahas adalah pengertian pajak menurut ahli-ahli yang ada, salah satunya adalah menurut Prof Dr Rochmat Soemitro S.H.

Dijelaskan juga mengenai jenis-jenis pajak. Pajak dapat dikelompokkan menjadi 3 yaitu golongan, sifat dan menurut lembaga pemungutannya. Menurut golongan pajak dapat dikelompokkan menjadi 2 yaitu : pajak langsung dan pajak tidak langsung. Pajak langsung seperti Pajak penghasilan yang tidak dapat dibebankan kepada orang lain, sedangkan pajak tidak langsung yang seperti Pajak Pertambahan Nilai (PPN) yang dapat dibebankan kepada orang lain. Menurut sifatnya pajak dapat dikelompokkan menjadi dua yaitu : pajak subjektif dan pajak objektif. Pajak subjektif adalah pajak yang pengenaannya memperhatikan keadaan wajib pajak contohnya seperti Pajak penghasilan. Apalagi sudah menikah berbeda dengan sebelum menikah dalam hal menghitung pajak penghasilannya. Pajak objektif adalah pajak yang pengenaannya 
memperhatikan objeknya seperti benda, keadaan, perbuatan maupun peristiwa yang mengakibatkan timbulnya kewajiban membayar pajak, tanpa memperhatikan keadaan pribadi subjek pajak dan tempat tinggal. Contohnya pajak pertambahan nilai (PPN).

Menurut lembaga pemungutnya maka pajak dibedakan menjadi pajak negara dan pajak daerah. Pajak negara adalah pajak yang dipungut oleh pemerintah pusat dan digunakan untuk membiayai rumah tangga negara pada umumnya. Contoh pajak pusat adalah PPN, PPh, PPN Bm. Sedangkan pajak daerah adalah pajak yang dipungut oleh pemerintah daerah baik daerah tingkat I (propinsi) maupun daerah tingkat II (pihak kabupaten/kota). Contoh pajak daerah adalah Pajak bumi dan bangunan (PBB) dan pajak kendaraan bermotor.

Dalam pertemuan ini dijelaskan juga mengenai tata cara pemungutan pajak. Ada juga cara pemungutan pajak dan sistem pemungutan pajak. Tata cara pemungutan pajak didasarkan kepada 3 stesel yaitu stesel pajak, stesel fiktif dan stesel campuran.

Sistem pemungutan pajak ada 3 yaitu : self assesment system, official assessment system, witholding system.

Untuk pencatatan dan pelaporan pajak di Indonesia kita tunduk kepada Direktorat Jenderal Pajak (DJP) yang berada di bawah otoritas kementrian keuangan RI.

Ada beberapa istilah yang perlu diperkenalkan kepada perusahaan seperti Pengusaha Kena Pajak (PKP), dijelaskan juga sedikit mengenai syarat menjadi PKP dan kewajibannya.



\section{Pelatihan ke -2}

Pelatihan ke-2 membahas tentang Pajak Pertambahan Nilai atau yang biasanya dikenal dengan istilah PPN. PPN ini adalah pajak yang dikenakan ke wajib pajak yang peredaran usahanya mencapai atau melebihi 4,8 milyar setahun atau yang dikukuhkan sebagai Pengusaha Kena Pajak (PKP). PPN yang dikenal ada 2 yaitu PPN masukan dan PPN keluaran. PPN masukan adalah ppn yang dikenakan atas pembelian barang/jasa oleh PKP. Sedangkan PPN keluaran adalah ppn yang dikenakan atas penjualan barang/jasa oleh PKP. Tarif PPN 10\% dari dasar pengenaan pajak (DPP).

Jasa yang tidak dikenai pajak pertambahan nilai adalah jasa tertentu dalam kelompok jasa sebagai berikut : jasa pelayanan kesehatan medis, jasa pelayanan sosial, jasa pengiriman surat dengan perangko, jasa keuangan, jasa asuransi, jasa keagamaan, jasa pendidikan , jasa kesenian dan hiburan, jasa penyiaran yang tidak bersifat iklan, jasa angkutan umum di darat, air serta jasa angkutan udara dalam negeri yang menjadi bagian yang tidak terpisahkan dari jasa angkutan udara luar negeri, jasa tenaga kerja, jasa perhotelan, jasa yang disedrikan oleh pemerintah dalam rangka menjalankan pemerintahan secara umum, jasa penyediaan tempat parkir, jasa telepon umu dengan menggunakan uang logam, jasa pengiriman uang dengan wesel pos dan jasa boga atau katering.

Pada pertemuan ini dijelaskan juga mengenai jurnal yang berkaitan dengan pajak pertambahan nilai misalnya seperti jurnal penjualan dan jurnal pembelian dengan ppn.

Setiap kali terjadi pembelian maka persediaan barang dagang akan bertambah. Dan sebaliknya apabila terjadi penjualan maka persediaan barang dagang akan berkurang. 
Berikut ini adalah jurnal untuk pembelian dan penjualan barang dagang dengan PPN (Pajak Pertambahan Nilai) menurut Agoes (2010) :

Saat Pembelian :

Dr. Pembelian /Persediaan barang dagang

$\mathrm{XXX}$

Dr. PPN Masukan Cr. Kas /hutang dagang

$\mathrm{XXX}$

XXX

Saat Penjualan :

Dr. Kas / Piutang dagang

$\mathrm{XXX}$

Cr. Penjualan

$\mathrm{XXX}$

Cr. PPN Keluaran

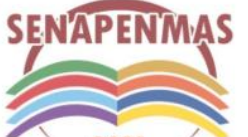

2021

Apabila terdapat perbedaan persediaan barang dagang yang di gudang dengan yang dicatat oleh bagian akuntansi maka akan dilakukan jurnal penyesuaian oleh bagian akuntansi (Weygandt et al, 2018). Dengan jurnal sebagai berikut (tidak perlu mencatat PPN):

\section{Sistem Perpetual}

Apabila Persediaan barang di gudang > catatan akuntansi

Dr. Persediaan barang dagang

XXX

Cr Harga Pokok Penjualan

XXX

Apabila persediaan barang di gudang < catatan akuntansi

Dr. Harga Pokok Penjualan xxx

Cr. Persediaan barang dagang

$\mathrm{XXX}$

\section{Sistem Periodik}

Menutup persediaan awal

Dr. Iktisar laba rugi

$\mathrm{XXX}$

Cr Persediaan barang dagang

XXX

Memunculkan persediaan akhir sesuai hasil pemeriksaan fisik

Dr. Persediaan barang dagang

XXX

Dr. Iktisar Laba rugi

$\mathrm{XXX}$

\section{Pertemuan ke-3}

Pertemuan ketiga ini membahas mengenai pajak penghasilan atau yang sering disingkat dengan Pph adalah pajak yang dikenakan terhadap penghasilan dalam bentuk apapun yang diterima atau diperolehnya dalam satu periode pajak. Misalnya gaji, bonus, tunjangan, dan nama lainnya. Pajak penghasilan dapat digolongkan menjadi dua yaitu pajak penghasilan bersifat final dan yang tidak bersifat final. Pajak penghasilan yang bersifat final misalnya : pph atas penghasilan dari usaha yang diterima/diperoleh wajib pajak yang memiliki peredaran bruto tertentu, PPH pasal 15 UU PPh untuk usaha tertentu, PPh pasal 4 ayat 2 UU PPh.

Di bawah ini ada beberapa contoh penjurnalan untuk PPh :

\section{PPh pasal 21}

Dikenakan atas gaji/bonus/penghasilan dan sejenisnya yang diperoleh oleh karyawan yang diberikan oleh perusahaan tiap bulannya.

Jurnalnya pada saat pembebanan gaji

$\begin{array}{lcc}\text { Dr. Beban Gaji } & \text { xxx } & \\ \text { Dr. Beban PPh 21 } & \text { Xxx } & \\ \text { Cr. Bank/ kas } & & \text { xxx } \\ \text { Cr. Hutang PPh 21 } & & \text { xxx }\end{array}$


Seminar Nasional Hasil Penelitian dan Pengabdian Kepada Masyarakat 2021

Pengembangan Ekonomi Bangsa Melalui Inovasi Digital Hasil Penelitian dan Pengabdian Kepada Masyarakat Jakarta, 21 Oktober 2021

Jurnalnya pada saat pembayaran hutang pph 21

Dr. Hutang PPh 21

$\mathrm{XXX}$

Cr. Bank/kas

$\mathrm{XXX}$

\section{$\frac{\text { PPh pasal } 23}{\operatorname{Salah}}$}

Salah satu yang diatur oleh $\mathrm{PPh}$ pasal 23 adalah sewa dan penghasilan lain yang berhubungan dengan penggunaan harta selain yang dikenakan oleh PPh pasal 4 ayat 2.

Jurnalnya pada saat pembebanan sewa:

Dr. Beban Sewa/sewa dibayar dimuka $\quad$ xxx
Dr. PPN Masukan
$\mathrm{XXX}$

Cr. Hutang PPh pasal 23

$\mathrm{XXX}$

Cr. Bank/Kas

$\mathrm{XXX}$

Jurnalnya pada saat pembayaran hutang PPh 23

Dr. Hutang PPh 23

$\mathrm{XXX}$

Cr. Bank/kas

$\mathrm{XXX}$

Apabila perusahaan yang mendapatkan pendapatan sewa maka jurnalnya :

Dr. Bank/kas $\quad$ xxx

Dr. PPh pasal 23 dibayar dimuka $\quad \mathrm{xxx}$

PPN Keluaran $\quad x x x$

Pendapatan sewa $\quad \mathrm{xxx}$

\section{PPh pasal 4 ayat 2}

$\mathrm{PPh}$ pasal 4 ayat 2 ini dikenakan atas sewa tanah dan bangunan.

Jurnal pada waktu pembebanan sewa

Dr. Sewa dibayar dimuka $\quad$ xxx

Dr. PPN Masukan Xxx

Cr. Hutang PPh pasal 4 ayat $2 \quad$ xxx

Cr. Bank/Kas $\quad \mathrm{Xxx}$

Jurnal pada waktu membayar hutang PPh pasal 4 ayat 2

Dr. Hutang PPh pasal 4 ayat 2 xxx

Cr. Bank/kas $\quad$ xxx

Dari sisi pihak yang menyewakan tanah dan bangunan

Dr. Bank/kas

Dr. Beban PPh 4 ayat 2

Cr. PPN Keluaran

Cr. Pendapatan sewa
$\mathrm{XXX}$

$\mathrm{XXX}$

$\mathrm{XXX}$

$\mathrm{XXX}$

\section{KESIMPULAN DAN SARAN}

Kegiatan PKM dilakukan dalam bentuk pelatihan yang menggunakan platform daring. Diharapkan pelatihan ini nantinya akan diterima dengan baik oleh peserta dan dapat dipraktekkan dalam kegiatan operasional perusahaan.

\section{Ucapan Terima Kasih (Acknowledgement)}

Kami mengucapkan terima kasih kepada pihak yang telah mendukung terlaksananya kegiatan Pengabdian Kepada Masyarakat ini terutama kepada Rektor Universitas Tarumanagara, LPPM 
Universitas Tarumanagara, Dekan FEB Universitas Tarumanagara dan pihak mitra PKM yaitu CV Amadeus Jaya Makmur

\section{REFERENSI}

Agoes, Sukrisno dan Estralita Trisnawati (2010). Akuntansi Perpajakan. Edisi 3. Jakarta: Salemba Empat.

Asfa, E.R \& Meiranto, W (2017). Pengaruh Sanksi Perpajakan, Pelayanan Fiskus, Pengetahuan dan Pemahaman Perpajakan, Kesadaran Perpajakan terhadap kepatuhan Wajib Pajak. Jurnal akuntansi Diponegoro. Vol 6. No. 3.

Darussalam, Danny Septriadi \& Khisi Armaya Dhora (2020). Konsep dan Aplikasi Pajak Penghasilan.. Jakarta :DDTC.

Prasetya, Gregorius Bela (2021). Analisis Penurunan Tarif Pph Badan Terhadap Perekonomian Kontrak Bagi Hasil Gross Split \& Multiplier Effect Bagi Perekonomian Pada Kegiatan Hulu Minyak Bumi di Indonesia. Jurnal kajian Ilmiah Perpajakan Indonesia. Vol 2.No. 2. April. ISSN 2686-5718

Pratiwi, Memi, Fadiah Nasaruddin \& Syamsu Alam (2021). Analisis Penerapan PP 23 Tahun 2018 pada Wajib Pajak UMKM. Jurnal ilmu Akuntansi Univesitas Islam Indonesia. Vol 3. No. 1. Maret. ISSN 2714-6359.

Resmi, Siti. (2011). Perpajakan.. Edisi 10. Jakarta: Salemba Empat

Suci, Yuli Rahmini (2017). Perkembangan UMKM (Usaha Mikro Kecil Menengah) di Indonesia. Jurnal Ilmiah Cano Economos. Vol 6. No. 1. Januari.

Sudjana, Nana (2010) . Dasar-dasar Proses Belajar, Bandung: Sinar Baru.

Sularsih, Hermi (2018). Dampak Peraturan Pemerintah No 23 tahun 2018 terhadap peningkatan pajak UMKM di kota Malang. Jurnal Akuntansi dan Manajemen. Vol 3. No.3. ISSN 2086-3659.

Weygandt, Kimmel, Kieso (2018). Financial Accounting. IFRS Edition. US : Wiley 